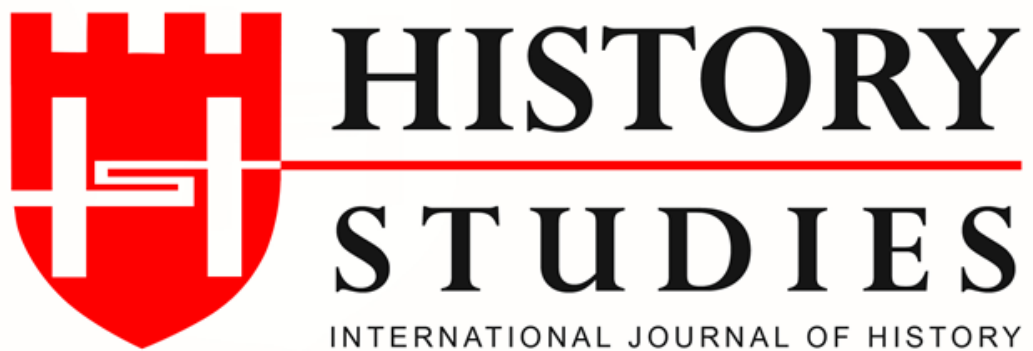

ISSN: 13094173 / (Online) 1309 - 4688 (Print)

Volume: 13, Issue: 3, June 2021

www.historystudies.net

\title{
HISTORY OF THE TURKISH-BELARUSIAN RELATIONS AND THE RUSSIAN FACTOR
}

Türkiye- Belarus İlişkileri Tarihi ve Rusya Faktörü

\section{Onuralp Doğan Çakır}

T.C. Dışişleri Bakanlığı onuralp.cakir@mfa.gov.tr

ORCID ID: 0000-0002-4406-3922

Makale Türü-Article Type : Araştırma Makalesi-Research Article

Geliş Tarihi-Received Date : $\quad$ 24.03.2021

Kabul Tarihi-Accepted Date : $\quad 24.05 .2021$

DOI Number : 10.9737/hist.2021.1014 

HISTORY STUDIES

Uluslararası Tarih Araştırmaları Dergisi International Journal of History

13/3, Haziran- June 2021

805-820

Araştırma Makalesi

\title{
HISTORY OF THE TURKISH-BELARUSIAN RELATIONS AND THE RUSSIAN FACTOR
}

\author{
Türkiye- Belarus Illişkileri Tarihi ve Rusya Faktörü
}

Onuralp Doğan Çakır

$\ddot{O} \mathbf{z}$

Türkiye ve Belarus'un ortak bir sınırı, ortak tarihi, kültürü veya ideolojisi bulunmamaktadır; ayrıca iki ülkenin devlet yapıları, ekonomi ve güvenlik anlayışları birbirinden çok farklıdır. Ancak bu durum, iki ülke arasındaki ilişkilerin önemli olmadığ 1 anlamına gelmemektedir. Aslında Türkiye ve Belarus coğrafi konumlarının bir sonucu olarak ticaret açısından muazzam bir potansiyele sahiplerdir. Bu yazıda iki taraflı işbirliği alanları, birbiriyle kültürel ve tarihsel açıdan derin bağlara sahip olmamalarına rağmen kendine has ortaklıklarını geliştirmeyi başaran bu ülkelerin ikili ilişkileri incelenmiştir. İki ülke arasında farklı alanlarda karşılaştırılma yoluna gidilmiştir. Ayrıca, ikili ilişkilerin kısa geçmişi, karşılıklı resmi ziyaretler ve kültürel temaslar da incelenmiştir.

Anahtar Kelimler: Türkiye, Belarus, Rusya, Siyaset, Siyasi tarih

\section{Abstract}

Turkey and Belarus have no common border, no common history, culture, or ideology; their understanding of state structure, economy and security differs a lot. However, it does not mean that the relations between these two countries are not important. Actually, they have enormous potential in terms of trade, as a result of their geographical locations. In this essay, we will examine the spheres of cooperation for Turkey and Belarus, the process of evaluation of the relations of these countries, which have achieved to develop their own partnership, regardless of absence of deep ties by cultural and historical means. The two countries are compared with each other in different aspects. Their short history of bilateral relations, official visits and cultural contacts are examined too.

Keywords: Turkey, Belarus, Economic Relations, Political Relations 


\title{
Introduction
}

Relations between Turkey and Belarus are not among the well-studied subjects neither in political, nor historical science. There are some good reasons for that unpopularity of this theme. The two countries do not have any significant political agenda, nor any major trading volume. Belarus is one of the less known countries in Turkey, among all fifteen ex-Soviet sovereign states. One of the reasons behind this fact is that Belarus has no any common border with Turkey, while these 5 ex-Soviet states have by land or sea. Secondly, most of the ex-Soviet nations have common culture and history with the Turks of Turkey. Within them are sovereign states like Azerbaijan, Kazakhstan, Turkmenistan, Uzbekistan and Kyrgyzstan, or autonomous regions like Tatarstan, Yakutia, Bashkortostan or Gagauzia. These countries and regions have Turkic origins, they are relatives to the Turkish people of the Turkish Republic, which makes them more interested and known, more or less, unlike Belarus.

Turkey and Belarus have no common border, no common history, culture, or ideology; their understanding of state structure, economy and security differs a lot. However, it does not mean that the relations between these two countries are not important. Even if they are not mentioned together so much, they have some similar roles, like having very important geopolitical locations. The countries have officially been calling themselves as a bridge between the East and the West, both in geographical and cultural terms. ${ }^{1} 2$

Actually, they have enormous potential in terms of trade, thanks to their locations. Both countries are located on different lines of the historical Silk Way, which means that today they are closely related to the popular transportation projects like Belt and Road. On the other hand, new trade route projects are discussed in North-South directions through rivers like Dniepr and Dniestr, as in the historical trade route from the "Varangians to the Greeks". ${ }^{3}$

Economies of these countries are mutually complementary, as they are developed in different directions; one with a liberal-capitalist oriented market, the other with a communist oriented one. Actually this can be seen as a good advantage, indeed. Since they are developed in different directions, it can be said that their markets are complements for each other. This fact is valid for the arms industry too. Once these two countries could realise the mutual advantage of sharing technology and experience, it would be beneficial for both sides. In the end, the Byelorussian SSR (Soviet Socialist Republic) played a key role as one of the most important arms supplier for the Soviet Union, until the last days of it. Today Belarus produces and exports a variety of arms, such as multiple launch rocket systems, anti-tank guided missile, radar systems, armoured cars, small arms etc. The defence industry within Turkey has specialised in 4x4, 6x6 and 8x8 armoured platforms, tracked infantry fighting vehicles, as well as main battle tanks, unmanned flying vehicles and missile rockets are manufactured by private or state companies.

In recent years, thanks to the high level visits, Turkey and Belarus have proven that they know how to find common ground. Both presidents visited each other, President of Turkey Recep Tayyip Erdogan visited Belarus one time, while President of Belarus Alexandr G. Lukashenko visited Turkey five times since 1994, with different purposes. Apart from that we have witnessed numberless visits of ministers and other high officials. A number of agreements have been signed

\footnotetext{
${ }^{1}$ Lukashenko: Belarus dolzhna byt' soyedinyayushchim mostom mezhdu Vostokom i Zapadom (Lukashenko: Belarus should be a connecting bridge between East and West) https://news.tut.by/politics/135389.html (In Russian), Access date: March 2, 2021.

2 Erdoğan: Türkiye, doğu-batı arasında köprü (Erdogan: Turkey, a bridge between East and West) https://www.hurriyet.com.tr/ekonomi/erdogan-turkiye-dogu-bati-arasinda-kopru-172390 Access date: March 12, 2021.

${ }^{3}$ SVERDLOV, M.B., Transit Routes in Eastern Europe in the 9th to 11th Centuries. Soviet Geography, (1970), pp.472-479.
}

\author{
History Studies \\ www.historystudies.net
}


in the field of trade, culture, education, defence etc. The numbers of the visits would increase in coming years, which would stimulate the relations.

However, is it possible and sustainable for a NATO member country to have a close relationship with an ex-Soviet Republic? To give the answer, we can think about the period just before the collapse of the Soviet Empire, when the world saw that the communist Soviet can have closer relations with the liberal-democratic world, by signing deals on various spheres. It was the case for any Western Block countries, even with the United States. If you think that it was an abnormal period, you can examine the Sino-US relations in 1970s. In a world without blocks, why closer relations between Turkey and Belarus should be surprising? It should not.

In this essay, we will examine the spheres of cooperation for Turkey and Belarus since the 1990 s, the process of evaluation of the relations of these countries, which have achieved to develop their own partnership, regardless of absence of deep ties by cultural and historical means. The two countries are compared with each other in different aspects. Their short history of bilateral relations, official visits and cultural contacts are examined too.

\title{
1. A Brief History of Diplomatic Relations
}

The Republic of Belarus is a relatively new state. It was founded in the last month of 1991, when the Soviet Union collapsed desperately. Besides that, Belarusian people have neither a deep history, nor experience of state tradition, as there was only one fully independent Belarusian state, which existed shortly in the interwar period. The Belarusian National Republic was founded in 1918. ${ }^{4}$ This young state ceased to exist just within a year, in 1919, despite significant efforts to save it. It was mostly because the territory was continually dominated by the German Imperial Army and the Russian Imperial Army during the First World War, and then the newly founded Bolshevik Red Army. People of Belarus had to wait until the end of the 20th century, in order to live in an independent state on their own.

There is possibly no essay about the Turkish - Belarusian relations that does not mention about the recognition of the independence of the new Republic of Belarus, by the Turkish government, as the first state to do so. In international relations, such kind of action means a lot for a state. To be recognised by the other states is very important for a state`s legitimisation, which guarantees the survival of it. That's why it would be remembered by the recognised country, as a sign of gratitude to the country that recognises the first. On 25 March 1992, relatively soon after this recognition, diplomatic relations were established between Turkey and Belarus. ${ }^{5}$ In 1992, the Embassy of the Republic of Turkey in the Republic of Belarus in Minsk was opened; and 1997 was the date of the opening of the Embassy of the Republic of Belarus in the Republic of Turkey, in the capital of the last. ${ }^{6}$

But at the initial stage of the development of relations, we see some certain troubles. In 1994, two attachés of the Turkish embassy, who was charged with "Activity incompatible with the status diplomat ", were sent from the Republic Belarus to Turkey. The Turkish side did not agree with the charges. Ministry of Foreign Affairs of Turkey assessed the actions of the Belarusian authorities as unjustified and unfair, and the Turkish government announced the cancellation all visits to Belarus at the highest level, ceased work on some bilateral agreements, suspended a $\$$

\footnotetext{
${ }^{4}$ SILITSKI V., Jr.; ZAPRUDNIK J.. The A to Z of Belarus. (2010, Scarecrow Press.) pp. 308-. ISBN 978-1-46173174-0.

5 Relations between Turkey and Belarus, the official site of the MFA of the Republic of Turkey http://www.mfa.gov.tr/relations-between-turkey-and-belarus.en.mfa Access date: March 2, 2021.

${ }^{6}$ Bilateral relations (Turkey and Belarus), the official site of the MFA of the Republic of Belarus

https://turkey.mfa.gov.by/en/bilateral_relations/political/relations/(In Russian), Access date: March 2, 2021.
}

\author{
History Studies \\ www.historystudies.net
}


100 million loan to Belarus, and cancelled the mechanism of action of the joint business council.

However, normalisation and further development of relations came soon. In 1996, there was the first official visit of the President of Belarus Alexandr G. Lukashenko to Turkey, the result of which was the signing of the Treaty of Friendship and Cooperation between the Republic of Belarus and the Republic of Turkey. The next meeting of the presidents of Belarus and Turkey took place in 1999 in Istanbul on the sidelines of the summit of the Organisation for Security and Cooperation in Europe. In 2010, the President of Belarus Lukashenka paid a second official visit to Turkey. As a result of the agreements reached in 2011, the Consulate General of the Republic of Belarus began its work in Istanbul. In April 2016, in Istanbul, during the summit of the Organisation of Islamic Cooperation, a meeting of the heads of states took place. In November 2016, we saw the first visit of the President of Turkey Recep T. Erdogan to Belarus. In May 2017, a meeting of the heads of Belarus and Turkey took place within the framework of the Belt and Road Forum in Beijing (PRC). In February 2019, the President of Belarus Lukashenko and Turkish President Erdoğan met in Sochi (Russian Federation) as part of the talks between the presidents of Russia, Turkey and Iran on a settlement in Syria. ${ }^{8}$

In April 2019, Belarusian President Lukashenko visited Turkey one more time. The Prime Minister of Belarus visited Turkey in 2014 and 2015. In February 2018, the Prime Minister of the Republic of Turkey Binali Yıldırım paid an official visit to the Republic of Belarus.

Today, there are bilateral friendship groups in the parliaments of the two countries. In August 2017, the Chairman of the Council of the Republic of the National Assembly of the Republic of Belarus M.V. Myasnikovich paid a visit to the Republic of Turkey. In July 2018, in Ankara, Mr. Myasnikovich took part in the inauguration ceremony of the President Erdoğan. In October 2018 in Antalya, the Chairman of the House of Representatives of the National Assembly of the Republic of Belarus V.P. Andreichenko took part in the third meeting of the speakers of the parliaments of the Eurasian countries. The return visit of the Chairman of the Grand National Assembly of Turkey Binali Yıldırım and the parliamentary friendship group to the Republic of Belarus took place in November 2018. ${ }^{9}$

Cooperation between the government bodies of the two countries has been actively developing. Meetings of the Intergovernmental Economic Commission, the Council for Business Cooperation, bilateral commissions on cooperation in the field of the defence industry, tourism, international road transport, and through the Ministry of Internal Affairs are held regularly. In 2013, Turkish Foreign Minister Ahmet Davutoğlu paid a visit to Belarus, which resulted in the signing of intergovernmental agreements on the mutual abolition of visas and on readmission. In the same year, the Minister of Foreign Affairs of the Republic of Belarus Vladimir V. Makei paid a visit to Turkey. A meeting of the Belarusian-Turkish joint intergovernmental economic commission was held. In December 2018, a working meeting of the heads of the foreign ministries of Belarus and Turkey took place within the framework of the 25th meeting of the OSCE Ministerial Council in Milan, Italy. ${ }^{10}$

\footnotetext{
${ }^{7}$ TIKHOMIROV, A.V. Sostoyaniye politicheskogo dialoga mezhdu Respublikoy Belarus' i Turetskoy Respublikoy v 1992-2009 gg. / A.V. TIKHOMIROV // Belarus' - Turtsiya: puti sotrudnichestva: materialy mezhdunar. nauch.prakt. konf., g. Minsk, 8 dekabrya 2009. - Minsk: Izd-vo «Chetyre chetverti» (The state of political dialogue between the Republic of Belarus and the Republic of Turkey in 1992-2009. / Belarus - Turkey: ways of cooperation: materials of the international. scientific - practical. conf., Minsk, December 8, 2009. - Minsk: Publishing house "Four quarters") (In Russian), 2010. P.43-47.

${ }^{8}$ Bilateral relations (Turkey and Belarus), the official site of the MFA of the Republic of Belarus https://turkey.mfa.gov.by/en/bilateral_relations/political/relations/ Access date: March 2, 2021.

${ }^{9}$ The same link

${ }^{10}$ The same link
}

\author{
History Studies \\ www.historystudies.net
}


In April 2019, within the framework of preparation for the visit of the President of the Republic of Belarus to Turkey, a working meeting of the Minister of Foreign Affairs of Belarus V.V. Makei was held with the Minister of Foreign Affairs of Turkey Mevlüt Çavuşoğlu. In August 2019, Minister M. Çavuşoğlu paid an official visit to the Republic of Belarus. ${ }^{11}$

Inter-MFA political consultations are held annually. The last round of consultations took place in February 2019 in Minsk at the level of heads of political departments. Since June 2014, visas for short-term trips of Belarusian and Turkish citizens have been cancelled on a reciprocal basis. Belarus and Turkey actively interact on international platforms, including the United Nations, the Organisation for Security and Cooperation in Europe, and the World Trade Organisation. The Institute of Honorary Consuls is actively used in the Belarusian-Turkish cooperation. Currently, Belarus has five honorary consuls: in Adana, Alanya, Antalya, Bursa and İzmir. ${ }^{12}$

2. The importance of Belarusian - Russian relations and the position of Belarus in terms of Turkish - Russian relations

Belarus has, may be, the closest ties with Russia that one country can have with another, even though they regularly have quarrels with each other in many cases. They have common history, culture, language, even common economy, market and borders.

Until the $18^{\text {th }}$ century Belarusian people, as a part of Ruthenian peoples, lived under many states in history. From the $13^{\text {th }}$ to the end of the $18^{\text {th }}$ century, the territory of modern Belarus was part of the Grand Duchy of Lithuania ${ }^{13}$, which became a part of the Polish-Lithuanian Commonwealth until the partition of the last. ${ }^{14}$ After this partition, territories of the modern Belarus became a part of the Russian Empire. With the fall of the Russian Empire, we see a shortlived independent Belarusian state, called the Belarusian National Republic, as we mentioned before. Then Belarus joined the Soviet Union as a founding member (others were Russia and Ukraine), under the name of Byelorussian SSR (BSSR). ${ }^{15}$ BSSR was one of the founding members of the United Nations among 51 countries, when it joined in 1945 as a part of the Soviet Union. BSSR signed the United Nations Charter; along with the Ukrainian Soviet Socialist Republic. After the dissolution of the Soviet Union in 1991, the newly independent Republic of Belarus retained its seat. When the Soviet Union was collapsing and ex-Soviet states sought independent, Belarus was one of the three states (others were Russia and Ukraine) that signed the Belavezha Accords on 8 December 1991, which led to dissolution of the union. ${ }^{16}$ It stayed as the closest country to the successor of the union, that's to say Russia. The two states signed lots of agreements that unite the destiny of the two states and peoples. They have become co-members of many international organisations too.

The Union State, which functions between Belarus and Russia since 1996 (then named Commonwealth of Belarus and Russia), citizens of both countries are guaranteed the right to move

\footnotetext{
${ }^{11}$ The same link

12 The same link

${ }^{13}$ Vialikaje Kniastva Litoŭskaje: Dziaržaŭny i palityčny lad // Encyklapiedyja historyi Bielarusi : U 6 t. — T. 2: Bielick - Himn / Bielarus. Encykl.; Redkal.: B. I. Sačanka (hal. red.) i inš.; Mast. E. E. Žakievič. — Mn.: BielEn, 1994. (Grand Duchy of Lithuania: State and political system // Encyclopedia of the History of Belarus: In 6 vols. Vol. 2: Belitsk - Anthem / Belarus. Encyclical; Ed .: BI Sachenko (Gal. Ed.), Etc .; Mast. EE Zhakevich) / s. 401-402.

${ }^{14}$ Rech' Pospolita // Bol'shaya rossiyskaya entsiklopediya : [v 35 t.] / gl. red. YU. S. Osipov. - M. : Bol'shaya rossiyskaya entsiklopediya, (Rzeczpospolita // Great Russian Encyclopedia: [in 35 volumes] / Ch. ed. S. OSIPOV. M.: Great Russian Encyclopedia) 2004-2017.

15 LUKASHEVICH D.A. Yuridicheskiy mekhanizm razrusheniya SSSR. - M, 2016. - S. 254-255. - $448 \mathrm{~s}$.

16 OSTROVSKIY A. V. Glupost' ili izmena? Rassledovaniye gibeli SSSR. M.: «Krymskiy most», (Ostrovsky A.V. Stupidity or treason? Investigation of the death of the USSR. M .: "Crimean bridge") 2011. — 864 s. ISBN 978-589747-068-6
}

\author{
History Studies \\ www.historystudies.net
}


and reside freely within the territory of the other party, allowing Belarusian citizens to travel freely in the territory of the Russian Federation and have the right to settle there to work or study, and vice versa. ${ }^{17}$ Apart from that, the two are members of Eurasian Economic Union (EAEU), the Commonwealth of Independent States (CIS) and the Collective Security Treaty Organisation (CSTO).

EAEU is an economic union with a single market, which was signed in 2014 (came into force in 2015) by the leaders of Belarus, Kazakhstan and Russia. In 2015 Armenia and Kyrgyzstan joined the union. ${ }^{18}$ The union aims the free movement of goods and services. It brings common policies in the macroeconomic sphere, transport, industry and agriculture, energy, foreign trade and investment, customs, technical regulation, competition and antitrust regulation. Policies for a single currency are among the plans for the future.

The CIS is a regional intergovernmental organisation of nine members (initially eleven, until Georgia and Ukraine left). The founding republics of the USSR, Russia, Belarus and Ukraine signed the Belavezha Accords on 8 December 1991. It was declared in the accords that the Union would cease to exist and proclaimed the CIS in its place. Within days, the Alma-Ata Protocol was signed, which declared that the Soviet Union was dissolved and that the newly founded Russian Federation will be its successor state. The Baltic States (Estonia, Latvia and Lithuania) declared that they will not be members, as they saw their membership in the Soviet Union as an illegal occupation. Georgia withdrew its membership in 2008. Ukraine ended its participation in CIS statutory bodies on 19 May $2018 .{ }^{19}$ The aim of the CIS is the cooperation in economic, political and military affairs. The organisation has interest in the coordination of trade, finance, lawmaking, and security. Cooperation on cross-border crime prevention is also among the priorities.

Finally, the last one is the CSTO. It is a military alliance. In 1992, Russia, Armenia, Kazakhstan, Kyrgyzstan, Tajikistan, and Uzbekistan signed the Collective Security Treaty (also referred to as the "Tashkent Pact" or "Tashkent Treaty"). ${ }^{20}$ Three other post-Soviet states (Azerbaijan, Belarus, and Georgia) signed the next year and the treaty. Five years later, six of the nine (except Azerbaijan, Georgia, and Uzbekistan) agreed to renew the treaty for five more years. Eventually in 2002 those six agreed to create the Collective Security Treaty Organization as a military alliance.

Russia has an enormous place in Belarus' foreign policy. For a third country, any good or bad relations with Russia would respectively mean a better or worse effect on ties with Belarus. Actually, that could have been the case, when Turkey and Russia had the SU-24 fighter jet crisis in 2015 .

As for Turkey and Russia, unlike historical relations, they developed very close ties throughout the 2000s. But, the fact that history does not have so positive pages for these two countries is not a coincidence. The two have lots of differences in foreign policies, which sometimes leads to conflict of interests. However, Turkey and Russia managed to turn a blind eye on these differences and concentrate on possibilities of cooperation. Surely, it was not possible to continue doing so,

\footnotetext{
${ }^{17}$ The agreement between the Republic of Belarus and the Russian Federation on providing the equal rights of citizens of the Republic of Belarus and the Russian Federation on freedom of travel, the choice of the place of stay and residence in the territories of the State Parties of the Union State, 2006 https://cis-legislation.com/document.fwx?rgn=21198 Access date: March 12, 2021

${ }^{18}$ The Official Site of the EAEU / About countries / http://www.eaeunion.org/?lang=en\#about-countries Access date: March 12, 2021

19 Poroshenko signs decree on final termination of Ukraine's participation in CIS statutory bodies / https://www.unian.info/politics/10123172-poroshenko-signs-decree-on-final-termination-of-ukraine-s-participationin-cis-statutory-bodies.html Access date: March 4, 2021

${ }^{20}$ From the Treaty to the Organization / The Official Site of the CSTO / https://en.odkb-csto.org/25years/ Access date: March 4, 2021
}

\author{
History Studies \\ www.historystudies.net
}


when the Syrian civil war dragged the two countries into a serious crisis on November 24, 2015, when the Turkish armed forces shot down a Russian SU-24 fighter jet, violating Turkey's airspace near the Syrian border. Till June 2016, political, economic and cultural links between the two countries were almost completely frozen. A number of sanctions against Turkey was imposed by Russia.

At this point, Belarus became a very important actor for Turkish foreign policy. Turkish President Erdoğan knew that he can rely on his Belarusian colleague, Lukashenko, who has open access to the Kremlin, in order to carry reports to Vladimir Putin of Russia and discuss some secret issues via him. Lukashenko himself would be very pleased to have such a role of mediator.

Besides, at the height of the crisis in the relations of Ankara and Moscow, Belarus was one of the most important transit hub for Turkish export products, mostly fruits and vegetables, to the Russian market. Therefore, Erdoğan pursued direct interests in Belarus until the end of the crisis. Now, with the improved Russian-Turkish relations, there seems to be no need in Minsk's mediation any longer. But Turkish ruling elite is still interested in keeping Minsk close, as there is no guarantee that Turkish - Russian relations will be save forever.

As for Belarus, it would prefer good relations between Turkey and Russia. Belarusian President Lukashenko would do anything to see the tension decreased. It was reflected on the official statement of the Belarusian Ministry of Foreign Affairs: "Such tragic and very dangerous incidents are deeply regrettable and deeply disturbing. Especially when they occur in a region where a bloody armed confrontation has already been going on for several years, and when our brotherly Russia and friendly Turkey become participants in such incidents." ${ }^{21}$

\title{
3. Relations of Turkey with its Western Allies and comparison of them with Turkish - Belarus relations
}

Was there any non-Christian European power which, from the Middle Ages to the early twentieth century, has ever been a permanent political actor in European politics? Yes, there is one: The Ottoman Empire. The fact that, after the conquest of Constantinople in 1453, Turkish imperial armies had even besieged the Habsburg capital of Vienna in 1529 and once more in 1683 had contributed to the sentiment of mortal menace by Islam, which was widely spread in the respublica christiana. Only in the eighteenth century could the idea of coexistence and good neighbourliness between Christian Europe and the Muslim Turkish Empire become more effective. ${ }^{22}$

Ottoman Empire had a major influence on modern Europe taking shape. From the beginning, till the end of the empire, Turks were involved in the political stage of Europe. The Empire became a part of the European economic system which gave way to the rise of modern capitalism. In $16^{\text {th }}$

century

Ottomans supported France against Habsburgs by sending troops, financial aid or through trade relations. The Ottomans joined the Concert of Europe after the Peace of Paris was signed in the end of the Crimean War. ${ }^{23}$

\footnotetext{
${ }^{21}$ Belarus' krayne obespokoyena intsidentom mezhdu "bratskoy Rossiyey" i "druzhestvennoy Turtsiyey" (Belarus is extremely concerned about the incident between "fraternal Russia" and "friendly Turkey") / https://news.tut.by/politics/474321.html Access date: March 2, 2021

${ }^{22}$ ZIEGLER, K. The peace treaties of the Ottoman Empire with European Christian powers. In R. Lesaffer (Ed.), Peace Treaties and International Law in European History: From the Late Middle Ages to World War One (pp. 338364). (2004, Cambridge: Cambridge University Press.) doi:10.1017/CBO9780511494239.016.

${ }^{23}$ PEARCE R. The Results of the Crimean War. History Review, 70, 2011, pp. $27-33$.
}

\author{
History Studies \\ www.historystudies.net
}


The Tanzimat era, which was a period of reform in the Ottoman Empire (began in 1839 and ended with the First Constitutional Era in 1876) that aimed modernisation, desiring to consolidate the social and political foundations of the imperial bureaucracy. ${ }^{24}$

The first initiators of reforms are the reformist sultans like Mahmud II, his son Abdulmejid I and prominent, often European-educated bureaucrats, who recognised that the old state institutions no longer met the needs of the time. There were some symbolic changes, such as uniforms. Thanks to that kind of changes, the rulers aimed at changing actually the mindset of the elite and people. Thus, officials were encouraged to wear a more western style of dress. The reforms were heavily influenced by the Napoleonic Code and French law under the Second French Empire. The increasing number of Ottoman students being educated in France became one of the main reasons of this fact. Changes were seen in military reforms, institutional and legal reforms; and systematic attempts at eliminating political corruption.

The founding elite of the Turkish Republic, the successor of the Ottoman Empire, was also among those that had their education mostly in Europe, or at least they were influenced by the West. Kemal Atatürk, the founder of the secular republic, saw the Western civilisation as the cure and the main goal to be reached. He also introduced the Latin-based Turkish alphabet, replacing the old Ottoman Turkish alphabet. Turkish women received equal civil and political rights during Atatürk's presidency. In particular, women were given voting rights in local elections by Act no. 1580 on 3 April 1930 and a few years later, in 1934, full universal suffrage. ${ }^{25}$

In the first years of the $21^{\text {st }}$ century, Turkish ruling elite kept seeing the West, particularly the United States, as very close partners, with whom Turkey had convergent geopolitical approaches from the Balkans to the Middle East, Caucasia, Central Asia, Eastern Mediterranean, and Southeast Asia. It had been the case on the earlier stages of the AK Party ruling too. In 2009, Ahmet Davutoğlu, then the chief foreign policy advisor to the Prime Minister Erdoğan, said during a visit to Washington that policies of Turkey and the United States are almost completely parallel with each other, in terms of many regions of the world. ${ }^{26}$

But today one cannot say that Turkey is in the best period of relations with the West, may be, it would be seen as even the worst. In order to understand what went wrong, one needs to go back at least to the transformation period of the Ottoman Empire into the Turkish Republic and to the period when many states were artificially created in the Middle East, from part of the rest of the Empire, by the victorious British and French forces after the World War I. These states naturally do not have the tradition of statehood, so today they are having trouble with ensuring stability, order and prosperity of citizens. State mechanism and bureaucracy in these countries are not sophisticated enough. In addition to that we see the continuation of interfering in domestic politics of the Middle Eastern countries by the Western powers. And one can stay that it didn't give any positive effect to the region, where sectarianist division was closely connected with the failure of Western policies towards Iraq or Syria. The situation left these countries more at risk of break-up than ever, which raised not only the prospect of an independent Kurdish state: but also being partially occupied by DAESH (the so called Islamic State of Iraq and the Levent). These destabilizing activities of Western powers made Turkish borders very vulnerable. Apart from that, the support from the United States to some Kurdish forces in Northern Syria, that' to say, the YPG, which is a branch of the PKK, terrorist organisation, was a turning point for Turkish relations with its Western allies. The Americans explained this by saying that YPG was fighting

\footnotetext{
${ }^{24}$ STRAUSS J. (2010). "A Constitution for a Multilingual Empire: Translations of the Kanun-ı Esasi and Other Official Texts into Minority Languages". In Herzog, Christoph; Malek Sharif (eds.). pp. 21-51.

25 Türkiye'nin 75 y1lı (75 Years of Turkey), Tempo Yayınc1lık, İstanbul, 1998, pp. 48, 59, 250.

26 “Davutoğlu'ndan İlginç İtiraf” (Interesting Confession from Davutoğlu) (In Turkish), Hürriyet, March 21, 2009, http://www. hurriyet.com.tr/davutoglundan-ilginc-itiraf-11256171 Access date: March 2, 2021.
}

\author{
History Studies \\ www.historystudies.net
}


alongside American forces against ISIS in Syria, which was naturally not satisfying for the Turkish authorities and Turkish public opinion.

One of the least favoured allies of Turkey is Greece, which is even hard to be called an ally by Turkish people (and vice versa). People of the two countries actually have much in common culturally, yet they share a troubled history. After living under the Ottoman rule for centuries, Greeks won their independence in 1830 (most of the parts of the modern Greece stayed within the Empire till 1913).

Turkey and Greece fought each other in many wars of major importance for the both countries: the Greco-Turkish War (1897), the First Balkan War of 1912 to 1913, the First World War (1914 to 1918) and finally the during the National Struggle. The two entered NATO in the same year, 1952. But relations between the two states deteriorated in 1960, because of the Cyprus issue, and the "Peace Operation" which was carried out by Turkish troops on the island. Today, Greece keeps its negative stance on Turkey's membership to the European Union. But this is not the only thing. There has been a military tension because of the confrontations over the Aegean dispute, which has strongly affected Turkish - Greek relations since the 1970s, and has twice led to crises coming close to the outbreak of military hostilities, in 1987 and in early 1996. Today, military tensions have risen again due to conflicts over maritime zones in the Aegean and Eastern Mediterranean. While Ankara is convinced that Greece is overprotected by the West, Athens sees Turkey as a spoilt country, as it continues receiving NATO arms, despite it keeps its presence in the northern regions of the island.

A similar confrontational encounter occurred with France because of different positions with Turkey. The two countries support different factions in Libyan and Syrian civil wars. In the eastern Mediterranean, Paris' support for Athens over energy exploration means another conflict with Ankara. France keeps joining military exercises with Greece in the eastern Mediterranean Sea, covering the area of the Greek-Turkish conflict, namely the islands of Kastellorizo. Although both France and Turkey are NATO members, it is difficult to resolve their differences within the framework of the organisation. Ankara attempts to become a major regional power and Paris tries to become a dominant player in the Mediterranean region. As a result, the differences and conflicts between France and Turkey become more complicated.

However, one of the most important issue that effected mostly on Turkey's relations with its Western allies is the failed deadly coup attempt on July 15, 2016, when a section of the Turkish military launched a coordinated operation in several major cities to topple the government and unseat the President Erdoğan. The coup attempt was one of the most tragic incidents in the history of the Republic of Turkey, even though there is a number of coup d'etats in the history of the country. It was a turning point for the entire country. The post-coup process signifies an adjustment to consolidate state power in Turkey. It is for sure that the coup attempt has been having a huge effect on Turkish foreign policy. It effected very badly the relations between Turkey and its Western Allies.

The attempt was to take over the state and eliminate the impact of the incumbent government, at the expense of 249 lives and injuring thousands of people, using heavy weaponry, including fighter jets, helicopters and tanks. Many people around the world heard about a terrorist organisation, called Fethullah Terrorist Organisation (FETÖ), for the first time; however in Turkey, it was the first idea that came to minds that the coup attempt could be organised by Fethullah Gülen, the leader of the organisation, who lives in Pennsylvania, the United States. There has been no doubt about that in the governmental circles, but the Western allies of Turkey were not convinced, especially the United States.

After the coup attempt, the Turkish - American relations had another difficult psychological test: the leader of FETÖ was still living in the United States, and Turkish authorities had been

\author{
History Studies \\ www.historystudies.net
}


asking for his extradition since 2014. ${ }^{27}$ Especially after 2016, thousands of documents, linking the coup attempt to Fetullah Gülen were sent to Washington, but without any concrete result. In addition to that, the tanker aircraft to provide fuel to pilots that would bomb strategical targets in Istanbul and Ankara were taken off from the Incirlik air base, in the Turkish city of Adana, which is used jointly with the US troops. ${ }^{28}$

On the contrary to the many allied countries, on the morning of July 16, 2016, Belarus was among the first states that expressed their support and condemned the coup attempt. Turkey was very grateful to Belarus for its loyal friendship and solidarity.

As reported, on July 16, 2016, the day after the attempted military coup in Turkey, President of Belarus Alexander Lukashenko sent a message to President Erdoğan, in which he expressed words of support and solidarity with the legitimate government of Turkey. "We express our gratitude to friendly countries, including Belarus, for the messages to Turkey with words of support and solidarity and phone calls to high-ranking officials in the government of our country to express support," the Turkish embassy in Belarus said. ${ }^{29}$ As reported, President of Belarus Alexander Lukashenko sent a message of support to President Erdoğan. Just after the coup attempt, the Belarusian Foreign Ministry issued a statement in which it "strongly condemned the criminal attempt to unlawfully overthrow the state power", and also stated that it "fully supports the Turkish leadership." (15) The massage was highly welcomed in Ankara, especially, if one considers that there was no such a quick and positive reaction from the Western allies of Turkey.

In the aftermath of the coup attempt, Ankara needed a new security policy; and may be a new understanding of foreign policy. From then on, Turkey decided to fight back the PKK, DAESH and FETÖ not only within borders, but also across it. This preemption policies had been brought forward before 2016 too, by the ex-Prime Minister Davutoğlu, who stated in his doctrine-like book, Strategical Depth ${ }^{30}$ that self-defence of Turkey should be carried out not only within Turkish borders, but also out. Mr. Davutoğlu actually emphasized on soft power too; however, with the radical change in Turkish foreign policy after the coup attempt, Turkish military staff found itself operating in many countries, as we indicated before. Ironically, dealing with many cross-border conflicts, Turkey has been cooperating mostly not with its Western allies, but countries like Russia, or Iran.

\title{
4. Economic Relations
}

Turkish government is not agreed with the idea that Turkey is shifting from West, to East, as it is claimed by some of its allies. Turkish high ranking officials lay stress on that Turkey is a candidate country to the EU, and a very important ally of NATO. ${ }^{31}$ But Ankara has no hesitation to remark that it seeks alternative markets and commercial ties. Considering the limited possibilities with its southern neighbours, Turkey revived its economic interest in the Commonwealth of Independent States (CIS), Russia, Ukraine, Central Asian republics, Belarus, and Moldova.

\footnotetext{
${ }^{27}$ Turkey: July 15 coup plotter gets 3,900+ years https://www.aa.com.tr/en/turkey/turkey-july-15-coup-plotter-gets-3900-years/2063317 Access date: March 12, 2021

28 Turkey's Erdogan calls on U.S. to extradite rival Gulen https://www.reuters.com/article/us-turkey-erdoganidUSBREA3S0A120140429 Access date: March 2, 2021

${ }^{29}$ Turtsiya blagodarit Minsk za podderzhku posle neudavshegosya perevorota (Turkey thanks Minsk for support after failed coup) https://sputnik.by/politics/20160718/1024256777.html Access date: March 7, 2021

${ }^{30}$ DAVUTOĞLU A. "Stratejik derinlik: Türkiye'nin uluslararası konumu"'. (Strategic Depth-The International Position of Turkey) Küre Yayınları, 2001.

${ }^{31}$ Çavuşoğlu: Turkey wants to expand Asian diplomatic ties https://www.iletisim.gov.tr/english/dis_basinda_turkiye/detay/cavusoglu-turkey-wants-to-expand-asian-diplomaticties Access date: March 7, 2021
}

\author{
History Studies \\ www.historystudies.net
}


Today, the European Union is divided. Brexit stands as a fact; "the deal is done". However, it left behind an unclear future for the union. Now in Turkey, there is much less expectations from the union, in terms of domestic balances, intelligence and security cooperation against terrorism on a common platform, and developing a feasible perspective for the future of Turkey-EU relations based on mutual economic and political interests rather than an all but evasive membership process.

Keeping it in mind, Ankara had to meet its needs for national security, besides, to have a good share from the world trade. If we look at the re-emergence of the idea of the Shanghai Cooperation Organisation (SCO) membership for Turkey*, we can observe that it had more to do with Turkish frustration with its Western identity than a commitment to bandwagon Russian and Chinese leadership in the Eurasian region. There is also a rather ambivalent interest in the Eurasian Economic Union, by which Turkey would deepen relations with Belarus and Kazakhstan. However, the question of the membership of Armenia in this organisation makes it almost impossible.

There had been a barrier (or remnants of it) in front of the idea of partnership with Russia, but the post-coup attempt climate eliminated it. Since then, the pro-government figures are engaging with "Eurasianist" groups in Russia. The publicised presence of Alexander Dugin ${ }^{32}$ in Ankara on July 14-15, 2016 (just before the coup attempt) and his meetings with the higher echelons of the ruling AK Party, including Prime Minister Yıldırım and Mayor of Ankara Melih Gökçek, gave idea about the future of relations with "Eurasia". The new Turkish doctrine of "Asia Anew" 33 is another indicator of that. This initiative aims to enhance trade volume with Asian countries. Here, one can see that the real Turkish goal is not just "pivoting to Asia." Actually, Turkey already has regional ties such as Japan, Indonesia, Malaysia, and South Korea that could have been utilised more to reach out to the continent. But in this project the priority belongs to China, which is an important partner for Turkey (and for Belarus, too, as both of Turkey and Belarus are somewhat included in the Chinese Belt and Road initiative, because both are located between China and Europe).

As for the Belarusian-Turkish direct economic relations, the Trade volume between Turkey and Belarus in 2019 amounted 900.3 million US Dollars (759.2 million dollars of Turkish exports to Belarus, 141,1 million US Dollars of Belarus export to Turkey). ${ }^{34}$ The largest share in bilateral exports and import of services belongs to: transportation services, business and tourism services. The basis of Belarusian exports is mostly formed by compounds containing a functional nitrile group, potash fertilizers, semi-finished products from unalloyed steel, wire unalloyed steel, linen. Knitted fabrics and fabrics, vegetables and fruits are among the most imported products by Belarus. In 2019, the volume of Turkish investments in the Belarusian economy made up USD 43.9 million US Dollars. In the same year, there were registered 139 companies with capital from Turkey in Belarus.

Total amount of investments by 50 Turkish firms operating in Belarus stands at 1.5 billion dollars. Turkish construction firms have undertaken 46 projects worth 918 million US Dollars since 1991, when they started working in the country. ${ }^{35}$ The Belarusian-Turkish joint economic commission is the main intergovernmental mechanism for strengthening bilateral cooperation in

\footnotetext{
32 “The Unlikely Origins of Russia's Manifest Destiny,” Foreign Policy, July 27, 2016,

http://foreignpolicy.com/2016/07/27/geopolitics-russia-mackinder-eurasia-heartland-dugin-ukraine-eurasianismmanifest-destiny-putin/ Access date: March 2, 2021

${ }^{33}$ Turkey to look East with Asia Anew initiative https://www.aa.com.tr/en/politics/turkey-to-look-east-with-asia-anewinitiative/1684818 Access date: March 2, 2021

${ }^{34}$ Belarus-Turkish trade and economic cooperation / the official site of the MFA of the Republic of Belarus

https://turkey.mfa.gov.by/en/torgovo_ekonomicheskaya_slujba/bel_turk/ Access date: March 2, 2021

35 The same link
}

\author{
History Studies \\ www.historystudies.net
}


trade, economic and investment spheres. 139 business entities with the participation of Turkish capital are registered in Belarus. Investment projects in the field of telecommunications, construction, light industry, metalworking and the chemical industry have been implemented in the country. Not only the Turkish side, but also the Belarusian industrial enterprises are interested in Turkish market. "BNH Petrokimya" LLC of "Belneftekhim" concern operates in Turkey, a representative office of "MAZ" OJSC is opened. In April 2019, the assembly production of MTZ tractors was launched in the city of Kirikkale. Work is underway to organise assembly plants for Gomselmash combines, construction and special equipment Amkodor, and to establish export of BELAZ dump trucks to the Turkish market. ${ }^{36}$

\title{
5. Cooperation in defence
}

The mutual cooperation is going on, in the military sphere too. Military education and defencetechnical industry are the main aspects of this cooperation. The sides are focused on the exchange of experience in the defence-technical industry. One as a NATO country, the other with a Soviet past and experience; the two have much to share with each other.

The fact that Turkey purchased S400 air defence system from Russia shows that it is interested in not only NATO weapons. Belarusian defence industry consists of manufacturing components for the systems manufactured by other countries, especially Russia, rather than producing whole system. That makes Belarus important for Turkish buyers of Russian defence systems and etc. A Minsk-based factory MZKT produces chassis, called MZKT-7930, on which S-400 could be mounted. ${ }^{37}$

HISTORY STUDIES

\section{Cultural Relaitons}

Soft power, public diplomacy and cultural diplomacy are gaining weight in relations between the states of the 21 st century. Such forms of relations are not based on direct propaganda, which can hardly be effective in the modern world. Their main goal is to make understandable to each other the civilizational features of their societies with different cultural and historical values. With this perception of cultural diplomacy, it becomes more universal than ordinary state propaganda. Such forms of cultural contacts are very effective in helping peoples to become better acquainted with each other's culture.

Political, cultural relations between Turkey and Belarus are developing every year. Their international legal basis is an intergovernmental agreement on cooperation in the fields of education, science, culture and sports, as well as a protocol on cooperation in the field of culture and art between the Ministry of Culture of Belarus and the Ministry of Culture and Tourism of Turkey. ${ }^{38}$

Bilateral days of culture and concerts are practiced in both countries. A continuous cooperation has been established between institutions such as national libraries, language school, and it is planned to open cultural centres in both countries. The flow of Turkish and Belarusian tourists is growing significantly. An increase in the number of joint marriages has become a positive indicator of mutual understanding between peoples.

Turkish radio, television, news programs, press, broadcasting of sporting events in Turkey have been increasingly involved in cultural life of Belarus in recent years. Such products of intellectual content play a dominant role in shaping the country's image. Another channel for the dissemination of Turkish culture in Belarus is Turkish television series. Note that today they have

\footnotetext{
${ }^{36}$ Anti-aircraft missile system S-400 'Triumph' https://missilery.info/missile/s400 Access date: March 2, 2021.

37 The same link

${ }^{38}$ Cooperation in the field of culture / the official site of the MFA of the Republic of Belarus

https://turkey.mfa.gov.by/ru/bilateral_relations/cultural/(In Russian), Access date: March 2, 2021.
}

\author{
History Studies \\ www.historystudies.net
}


generally reached the level of a global presentation of Turkey. And for the first time, the phenomenon of Turkish TV series outside Turkey manifested itself in the Middle East, Latin America, Europe and then became much more widespread, including the post-Soviet countries.

Back in the late 1990s - early 2000s. Serials from the USA, Mexico and Brazil dominated the market in Turkey. The situation began to change only with the beginning of a general development of the national film industry and the liberalisation of the media sphere as a whole. Since the beginning of the 2000s, production and broadcasting of Turkish serials grew steadily not only in Turkey, but also abroad. Today, Turkey is the world's second largest exporter of television series just after the United States. The revenue from the sale of TV series abroad amounts to hundreds of millions of dollars, and the audience includes more than 100 countries, including Belarus. ${ }^{39}$ There is also a growing tourist flow to the country, in particular to Istanbul, which in recent years has become a kind of "Hollywood" in the Turkish film industry.

According to the Turkish company Ay Yapım, producer of the famous historical series "Muhteşem Yüzyıl" (Magnificent Century, a historical fiction television series about the ruling era of Süleyman the Magnificent of the Ottoman Empire) and the leader of the film industry in Turkey, some of the most popular episodes are sold abroad for $\$ 150,000$ or more (for comparison: 5-7 years ago the price of the series was $\$ 4,000$ (18). The series met with some criticism from historians, directors, religious leaders, even the President of Turkey, but it remains the most successful and most expensive national series, which successfully attracts Belarusian viewers too. 40

\title{
Conclusion
}

Relations between allies of the current century are very different from those that were in the last century, when everything was clearly formulated; it was clear who the friend is and who the enemy was. Now, the so-called allies can instantly find themselves on different fronts of different quarrels. So, it is not a coincidence that Turkey and Belarus many times had disagreements with its allies. And that is why the close relations between these countries, which were on opposite fronts of the Cold War, should not surprise anyone too. In the end, policies of both countries can be named as sui generis. They both know how to find balance in relations with their partners. Geopolitical locations thought them how to achieve it.

One of the most important factors in the positive dynamics of the Belarusian-Turkish relations has is that they have always being built exclusively on a pragmatic basis and free from ideological constraints. The absence of any conflicts between countries always created a favourable climate in all areas for the further development of relations. For Belarus, it was (and is) utmost important that Turkey did not join any restrictions or sanctions, as they were imposed by Turkey's NATO allies. For Turkey, Belarus stands as a good friend that did never intervene in domestic affairs of Ankara, and supported it against any attempt of that kind of intervention. We see it not only in 1990 s, but in the $21^{\text {st }}$ century too.

Absence of a potential conflict in Turkish - Belarusian relations created a favourable climate for the further development of bilateral relations. Therefore, there is a good reason to believe that the trend towards an improvement in political relations between the two countries will continue not only in the near future, but also in the long term, as it was the case during the whole history of relations.

\footnotetext{
${ }^{39}$ CANDEMIR Y. Turkish Soap Operas: The Unstoppable Boom. / Blogs WSJ //http://blogs.wsj.com/middleeast/2013/04/29/turkish-soap-operas-the-unstoppable-boom/ Access date: March 2, 2021

40 The same link
}

\author{
History Studies \\ www.historystudies.net
}




\section{References}

BRAUDEL, Fernand (1985), Civilization and Capitalism, 15th - 18th Century, The Structures of Everyday Life (Volume I), translated by Siân Reynolds, Harper \& Row Publishers: New York.

Bielaruś - Turcyja : [chronika padziej] (2006) // Viesn. M-va zamiež. spraŭ Resp. Bielaruś. № 2. - Šifr NBB: ZOK7441 (Belarus - Turkey: [chronicle of events] // Spring. MFA of the Rep. Belarus. (2006) - № 2. -NBB code: ZOK7441).

KUPCHINA, Ye. N. Perspektivy belorussko-turetskogo sotrudnichestva na sovremennom etape (2013) / Ye. N. Kupchina // Problemy upr. -№ 2. - Shifr NBB: ZOK9455 (Kupchina, E. N. Prospects of the Belarusian-Turkish cooperation at the present stage (2006) / E. N. Kupchina // Problems of exercise. - No. 2. -NBB code: ZOK9455).

TIKHOMIROV, A. V. Politicheskiye aspekty belorussko-turetskogo vzaimodeystviya v 2010 g. (2011) Belarus' - Turtsiya: puti sotrudnichestva : materialy vtoroy mezhdunar. nauch.-prakt. konf. (25 fevr. 2011 g., g. Minsk) / Fak. mezhdunar. otnosheniy Belorus. gos. un-ta [i dr.]. - Minsk. - Shifr NBB: 1N//310782(039) (TIKHOMIROV, A. Political aspects of the Belarusian-Turkish interaction in 2010 (2011) / A. V. Tikhomirov // Belarus - Turkey: ways of cooperation: materials of the second international. scientificpractical conf. (February 25, 2011, Minsk) / Faculty of international relations of Belarus [and others]. - Minsk, NBB code: 1H // 310782 (039)).

KULEVSKAYA S. V usloviyakh krizisa: Belarus' - Turtsiya, torgovo-ekonomicheskoye sotrudnichestvo (2009) / podgot. // Germes. - № 2. -Shifr NBB: ZOK6513 (In crisis conditions: Belarus - Turkey, trade and economic cooperation (2009) / prep. S. Kulevskaya // Hermes. № 2. -NBB code: ZOK6513).

GORDZYALKOVSKIY, A. Nuzhen bereg turetskiy : krupneyshiye turets. investory $\mathrm{v}$ Belarusi (2013)/ A. GORDZYALKOVSKIY // Biznes-revyu. - № 3. -Shifr NBB: ZOK12052 (GORDZYALKOVSKY, A. We need a Turkish coast: the largest Turkish. investors in Belarus (2013) / A. GORDZYALKOVSKY // Business review. - 2013. No. 3. - NBB code: ZOK12052).

ROZALIYEV YU. N. (1980) Ekonomicheskaya istoriya Turetskoy Respubliki. (1980) Otvetstvennyy redaktor A. Iskanderov M.: Nauka. (ROZALIEV Yu. N. Economic history of the Turkish Republic. Managing editor A. Iskanderov, Moscow).

YAĞMUR, D. Turetsko-belorusskiye ekonomicheskiye otnosheniya (2013) // Problemy upr. - № 2 .

YAGMUR, D. Turkish-Belarusian economic relations (2013) // Problems of exercise. - No. 2).

ELDEM, Z. Razvitiye vneshney politiki Turtsii v KHKH - nachale KHKHI v. (2009) // Belarus' - Turtsiya: puti sotrudnichestva: materialy mezhdunar. nauch.-prakt. konf., g. Minsk. - Minsk: Izd-vo «Chetyre chetverti», 2010. (ELDEM, Z. Development of Turkish foreign policy in the XX - early XXI century. (2009) // Belarus - Turkey: ways of cooperation: materials of the international. scientific-practical conf. - Minsk: Publishing house "Four quarters").

SEVER Ayşegül (1992). Soğuk Savaş Kuşatmasında Türkiye, Batı ve Orta Doğu. 1945-1958. (Turkey, the West and the Middle East during the Cold War siege) İstanbul.

HORAK, Stephan M. (1974) "Belorussia: Modernization, Human Rights, Nationalism." Canadian Slavonic Papers 16.3 
SKINNER, Barbara. (2012) The Western Front of the Eastern Church: Uniate and Orthodox Conflict in Eighteenth-Century Poland, Ukraine, Belarus, and Russia.

JANOWICZ, Sokrat (1999). Forming of the Belarussian nation. RYTM. pp. 247-248.

MARPLES, David. 'Our Glorious Past': Lukashenka's Belarus and the Great Patriotic War (2014, Columbia University Press). 


\section{Summary}

Relations between Turkey and Belarus are not among the well-studied subjects neither in political, nor historical science. That is actually understandable, as Turkey and Belarus have no common border, no common history, culture, or ideology; their understanding of state structure, economy and security differs a lot. However, it does not mean that the relations between these two countries are not important. Actually, they have enormous potential in terms of trade, as a result of their geographical locations. Economies of these countries are mutually complementary, as they are developed in different directions; one with a liberal-capitalist oriented market, the other with a communist oriented one.

There is possibly no essay about the Turkish - Belarusian relations that does not mention about the recognition of the independence of the new Republic of Belarus, by the Turkish government, as the first state to do so in 1992. In recent years, thanks to the high level visits, Turkey and Belarus have proven that they know how to find common ground. Both presidents visited each other, President of Turkey Recep Tayyip Erdogan visited Belarus one time, while President of Belarus Alexandr G. Lukashenko visited Turkey five times since 1994, with different purposes. Apart from that we have witnessed numberless visits of ministers and other high officials. A number of agreements have been signed in the field of trade, culture, education, defence etc. The numbers of the visits would increase in coming years, which would stimulate the relations.

However, is it possible and sustainable for a NATO member country to have a close relationship with an ex-Soviet Republic? To give the answer, we can think about the period just before the collapse of the Soviet Empire, when the world saw that the communist Soviet can have closer relations with the liberal-democratic world, by signing deals on various spheres. It was the case for any Western Block countries, even with the United States. If you think that it was an abnormal period, you can examine the Sino-US relations in 1970s. In a world without blocks, why closer relations between Turkey and Belarus should be surprising? It should not.

On the contrary to the many allied countries, on the morning of July 16, 2016, Belarus was among the first states that expressed their support and condemned the coup attempt. Turkey was very grateful to Belarus for its loyal friendship and solidarity.

So, one of the most important factors in the positive dynamics of the Belarusian-Turkish relations has is that they have always being built exclusively on a pragmatic basis and free from ideological constraints. The absence of any conflicts between countries always created a favourable climate in all areas for the further development of relations. For Belarus, it was (and is) utmost important that Turkey did not join any restrictions or sanctions, as they were imposed by Turkey's NATO allies. For Turkey, Belarus stands as a good friend that did never intervene in domestic affairs of Ankara, and supported it against any attempt of that kind of intervention. We see it not only in 1990s, but in the $21^{\text {st }}$ century too.

Russia has an enormous place in Belarus' foreign policy. For a third country, any good or bad relations with Russia would respectively mean a better or worse effect on ties with Belarus. Actually, that could have been the case, when Turkey and Russia had the SU-24 fighter jet crisis in 2015.

At this point, Belarus became a very important actor for Turkish foreign policy. Turkish President Erdoğan knew that he can rely on his Belarusian colleague, Lukashenko, who has open access to the Kremlin, in order to carry reports to Vladimir Putin of Russia and discuss some secret issues via him. Lukashenko himself would be very pleased to have such a role of mediator.

Besides, at the height of the crisis in the relations of Ankara and Moscow, Belarus was one of the most important transit hub for Turkish export products, mostly fruits and vegetables, to the Russian market. Therefore, Erdoğan pursued direct interests in Belarus until the end of the crisis. Now, with the improved Russian-Turkish relations, there seems to be no need in Minsk's mediation any longer. But Turkish ruling elite is still interested in keeping Minsk close, as there is no guarantee that Turkish - Russian relations will be save forever.

Absence of a potential conflict in Turkish - Belarusian relations created a favourable climate for the further development of bilateral relations. Therefore, there is a good reason to believe that the trend towards an improvement in political relations between the two countries will continue not only in the near future, but also in the long term, as it was the case during the whole history of relations.

In this essay, we will examine the spheres of cooperation for Turkey and Belarus, the process of evaluation of the relations of these countries, which have achieved to develop their own partnership, regardless of absence of deep ties by cultural and historical means. The two countries are compared with each other in different aspects. Their short history of bilateral relations, official visits and cultural contacts are examined too.

\section{History Studies \\ www.historystudies.net}

